\title{
PENGARUH VARIASI GULA PASIR TERHADAP WAKTUPENGOMPOSAN DITINJAU DARI RASIO C/N PADA SAMPAH SAYURANDI PASAR JATI BANYUMANIK DENGAN PENAMBAHAN BIOAKTIVATOR LINGKUNGAN
}

\author{
Mochtar Hadiwidodo ${ }^{1}$, Endro Sutrisno ${ }^{1}$, Azzura Sabrina ${ }^{1, *)}$ \\ ${ }^{1}$ Departemen Teknik Lingkungan, Fakultas Teknik UNDIP JI. Prof. H. Sudarto, SH Tembalang, \\ Semarang, Indonesia, 50275
}

email:azzura.rara@yahoo.com

\begin{abstract}
Abstrak
Sampah sayuran di Pasar Jati Banyumanik biasa dibuang tanpa dilakukan pemanfaatan dan pengolahan. Padahal, sampah sayuran dapat dimanfaatkan sebagai bahan baku pengomposan karena memiliki kandungan karbon, nitrogen, fosfor dan kalium yang dibutuhkan oleh tanaman dan kesuburan tanah. Selain itu, perlu penambahan gula dibutuhkan untuk mikroorganisme yang akan merombak pati, lemak, protein, dan selulosa di dalam gula. Penelitian ini bertujuan untuk mengetahui pengaruh variasi gula pasir terhadap waktu pengomposan ditinjau dari rasio $\mathrm{C} / \mathrm{N}$ pada sampah sayuran di Pasar Jati Banyumanik dengan penambahan bioaktivator lingkungan. Gula pasir yang ditambahkan divariasikan dari 0 sampai60 gram Proses pengomposan dilakukan selama 14 hari. Kompos yang diperoleh kemudian dianalisis suhu, $\mathrm{pH}$, kadar air, C-Organik, N-Total, P-Total, K-Total, penyusutan kompos, warna dan bau. Hasil analisis dibandingkan dengan SNI 19-7030-2004. Analisis kompos dilakukan pada hari ke 0, 3, 7,10 , dan 14 . Waktu kematangan kompos optimum ditinjau dari rasio $\mathrm{c} / \mathrm{n}$ yang dapat dicapai kompos dengan variasi gula pasir sebanyak 40 gram pada reaktor G3. Seluruh parameter yang diuji telah memenuhi standar kompos matang SNI 19-7030-2004.
\end{abstract}

Kata Kunci : sampah sayuran, gula pasir, bioaktivator lingkungan, kematangan kompos, waktu optimum

\begin{abstract}
Vegetable waste in Pasar Jati Banyumanik is usually being directly thrown away without any further process. Vegetable waste is suitable as raw material for composting because it has the carbon $(\mathrm{C})$, nitrogen $(\mathrm{N})$, phosphor $(\mathrm{P})$ and potassium $(\mathrm{K})$ content needed by plants and soil fertility. This purpose of this research to determine the effect of variations in granulated sugar on composting time in terms of the $\mathrm{c} / \mathrm{n}$ ratio of vegetable waste in Pasar Jati Banyumanik with the addition of environmental bioactivators. The variation of sugar used is 0 grams, 20 grams, 30 grams, 40 grams, 50 grams, and 60 grams. The composting process is carried out for 14 days. The compost obtained was analyzed for temperature, $\mathrm{pH}$, moisture content, C-Organic, N-Total, P-Total, K-Total, shrinkage of compost, color and odor. The results of the analysis are compared with SNI 19-7030-2004. Compost analysis was carried out on days $0,3,7,10$, and 14. The optimum compost maturity time was observed from the ratio of $c / n$ which can be achieved by composting with 40 grams of sugar in the G3 reactor. All parameters tested have met the standards of mature compost SNI 19-7030-2004.
\end{abstract}

Keywords: Vegetable Waste, Variation of Granulated Sugar, Environmental Bioactivator, Optimum Time,Compost Maturity

\section{Pendahuluan}

Sampah merupakan masalah yang paling banyak ditemui di Indonesia. Semakin banyak sampah maka semakin berbahaya juga dampak terhadap lingkungan. Menurut Mulyani (2014), jika tidak cepat ditangani, sampah akan menimbulkan berbagai macam dampak negatif. Sistem pengolahan sampah yang bersifat efisien dan ramah lingkungan mutlak diperlukan. Sampah harus dilihat 
sebagai bahan baku yang dapat diproses menjadi produk komersial yang tidak berdampak negatif bagi lingkungan.Data dari Dinas Lingkungan Hidup Kota Semarang menunjukan bahwa produksi sampah perkotaan dari tahun ke tahun terus meningkat seiring dengan laju pertumbuhan penduduk. Volume rata-rata per hari sampah di Kota Semarang pada tahun 2016 yaitu sampah terangkut sebesar 3897,04 m3 dan sampah produksi sebesar $5080 \mathrm{~m} 3$. Sedangkan untuk persentase komposisi sampah di Kota Semarang yaitu: organik $78,34 \%$, kertas 5,41\%, plastik 13,21\%, Kain $1,68 \%$, dan sampah lain $1,36 \%$. Pengolahan sampah organik belum optimal teratasi (Dinas Lingkungan Hidup Kota Semarang, 2017). Salah satu cara untuk mengurangi sampah yaitu dengan mengolah sampah menjadi kompos.

Kualitas kompos dapat dilihat dengan memperhatikan standar persyaratan teknis pupuk organik. Kompos berkualitas dapat ditandai dengan kompos yang sudah matang dan stabil. Menurut SNI 19-7030-2004 Kompos yang sudah matang memiliki kisaran $\mathrm{pH}$ 6,8-7,49 atau mendekati netral. Rasio C/N untuk pupuk yang telah matang yaitu kurang dari 20. Kompos yang sudah matang memiliki kandungan Karbon sebesar 9,8-32\%, Nitrogen dengan minimal 0,4\%, Phospor dengan minimal $0,10 \%$, dan Kalium dengan minimal $0,20 \%$.

Kecamatan Banyumanik merupakan salah satu kecamatan di Kota Semarang. Salah satu masalah yang ditemui di Kecamatan Banyumanik yaitu terdapat di Pasar Jati Banyumanik. Setiap harinya Pasar Jati Banyumanik menghasilkan sampah sayuran hasil dari para pedagang. Sampah sayuran di Pasar Jati Banyumanik dibuang begitu saja tanpa dilakukan pengolahan. Berdasarkan masalah tersebut, perlu penerapan teknologi untuk mengatasi limbah padat dengan menggunakan teknologi daur ulang limbah padat menjadi produk bernilai tinggi kompos. Pengomposan dianggap sebagai teknologi berkelanjutan karena tujuannya untuk pelestarian lingkungan, keselamatan manusia, dan nilai ekonomi. Teknologi pengolahan limbah padat meliputi pembuatan kompos. Pada kali ini pengomposan dilakukan dengan memvariasikan gula pasir pada pengomposan sampah sayuran dengan penambahan Bioaktivator Lingkungan guna meningkatkan proses dekomposisi. Mikroorganisme mulai merombak pati, lemak, protein, dan selulosa di dalam gula. Pemilihan penelitian ini dikarenakan belum adanya informasi mengenai Pengaruh Variasi Gula Pasir Terhadap Waktu Pengomposan Ditinjau dari Rasio C/N Pada Sampah Sayuran di Pasar Jati Banyumanik dengan Penambahan Bioaktivator Lingkungan.

\section{Metode Penelitian}

Penelitian ini berupa penelitian eksperimental skala laboratorium yang dilakukandi Laboratorium Teknik Lingkungan, Universitas Diponegoro. Terdapat tahap uji pendahuluan pembuatan bioaktivator lingkungan dari sampah sayuran dan uji karakteristik bahan sebelum dimulainya penelitian. Uji kadar C-Organik, N-Total dan P-Total secara spektrofotometri. Sedangkan uji K-Total dilakukan menggunakan AAS.

\section{Pelaksanaan Penelitian}

Penelitian ini menggunakan 6reaktor. Tahap pertama penelitian yaitu membuat reaktor sesuai dengan jumlah komposisi sampah yang akan diolah. Reaktor yang digunakan terbuat dari pot bunga. Pembuatan mengacu buku Penanggulangan Limbah oleh Sunarsih (2018).

Tahap kedua yaitu mengembang biakkanBioaktivator Lingkungandengan cara cacahan diberi tambahan bubuk Bioaktivator Lingkungan yang memiliki komposisi starbio, Aspergillus niger, EM4, necotro dan MOL sampah sayuran. Tahapan mengembang biakkan Bioaktivator Lingkungan mengacu pada penelitian Kusumawardhani (2018).

Tabel 1. Jumlah Bahan Pengomposan dan Variasi Gula Pasir

\begin{tabular}{|c|c|c|}
\hline $\mathbf{R}$ & Komposisi & Perlakuan \\
\hline G0 & $\begin{array}{c}\text { Sampah sayuran } 10 \mathrm{~kg}+ \\
100 \text { gram Bioaktivator } \\
\text { Lingkungan }\end{array}$ & $\begin{array}{l}\text { Tanpa Gula } \\
\text { Pasir }\end{array}$ \\
\hline G1 & $\begin{array}{c}\text { Sampahsayuran } 10 \mathrm{~kg}+ \\
100 \text { gram Bioaktivator } \\
\text { Lingkungan }\end{array}$ & $\begin{array}{l}\text { Gula Pasir } 20 \\
\text { gram }\end{array}$ \\
\hline G2 & $\begin{array}{c}\text { Sampahsayuran } 10 \mathrm{~kg}+ \\
100 \text { gram Bioaktivator } \\
\text { Lingkungan }\end{array}$ & $\begin{array}{l}\text { Gula Pasir } 30 \\
\text { gram }\end{array}$ \\
\hline G3 & $\begin{array}{c}\text { Sampahsayuran } 10 \text { kg+ } \\
100 \text { gram Bioaktivator } \\
\text { Lingkungan }\end{array}$ & $\begin{array}{l}\text { Gula Pasir } 40 \\
\text { gram }\end{array}$ \\
\hline G4 & $\begin{array}{c}\text { Sampahsayuran } 10 \mathrm{~kg}+ \\
100 \text { gram Bioaktivator } \\
\text { Lingkungan }\end{array}$ & $\begin{array}{l}\text { Gula Pasir } 50 \\
\text { gram }\end{array}$ \\
\hline G5 & $\begin{array}{c}\text { Sampah sayuran } 10 \mathrm{~kg}+ \\
100 \text { gram Bioaktivator } \\
\text { Lingkungan }\end{array}$ & $\begin{array}{l}\text { Gula Pasir } 60 \\
\text { gram }\end{array}$ \\
\hline
\end{tabular}

Tahap ketiga yaitu mengumpulkan sampah sayuran yang di ambil dari Pasar 
Banyumanik, Kecamatan Banyumanik. Sampah sayuran dibawa keLaboratorium Teknik Lingkungan untuk ditimbang sesuai kebutuhan penelitian. Setelah itu dilakukan uji pendahuluan yang dimana tujuan uji pendahuluan ini untuk mengetahui kandungan yang ada di dalam bahan pengomposan. Uji yang dilakukan terhadap sampah sayuran dan gula pasir sebagai bahan kompos antara lain $\mathrm{C}, \mathrm{N}, \mathrm{P}, \mathrm{K}$, rasio $\mathrm{C} / \mathrm{N}$, kadar air dan pengujian $\mathrm{pH}$.

Tahap keempat yaitu penelitian inti, semua bahan pengomposan di masukan kedalam 6 reaktor dengan memvariasikan jumlah gula pasir pada setiap reaktor. Jumlah bahan dan variasi gula pasir dalam penelitian ini tersaji dalam Tabel 1.

\section{Hasil dan Pembahasan}

\section{Kadar Air}

Pengukuran kadar air dilakukan setiap hari selama 14 hari. Kadar air harus tetap dijaga dalam proses pengomposan agar tetap memenuhi syarat optimal. Berikut merupakan hasil pengukuran kadar air pengomposan selama 14 hari dapat dilihat pada grafik berikut ini:

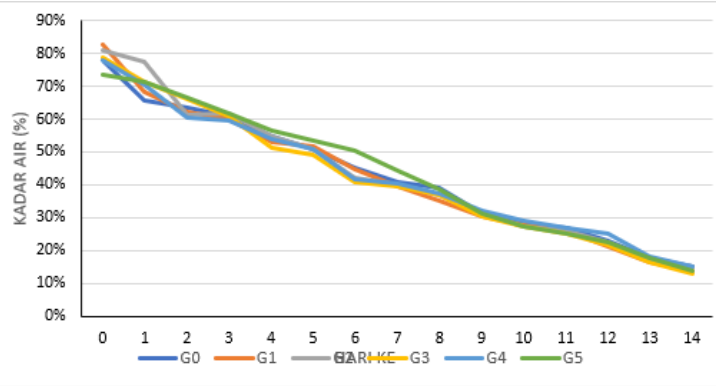

Gambar 1.Grafik Hubungan Kadar Air Terhadap Waktu Pengomposan

Secara umum kadar air setiap reaktor mengalami penurunan selama waktu pengomposan. Pada hari ke- 0 yaitu pada hari awal pengomposan, kadar air tertinggi berada pada reaktor $\mathrm{G} 1$ yaitu sebesar $82,652 \%$ dan yang kadar air terendah yaitu G5 sebesar $73,667 \%$. Pada hari ke- 5, reaktor G3 telah memenuhi syarat kompos matang yaitu sebesar 49,135\%.Pada hari ke-6, seluruh kadar air pada setiap reaktor sudah sesuai dengan standar SNI 19-7030-2004, dengan kadar air tertinggi dimiliki oleh reaktor G5 yaitu sebesar $50,435 \%$. Penurunan kadar air terjadi karena adanya pengadukan yang dilakukan setiap sehari sekali. Menurut Amanah (2012), pengadukan pun terus dilakukan untuk memberikan suplai udara bagi proses dekomposisi dan mengurangi kadar air.

\section{Suhu}

Pengukuran suhu dalam penelitian ini dilakukan 1 kali setiap hari dengan waktu pengukuran suhu pada kisaran pukul 08.00 hingga pukul 10.00. Pengukuran suhu dilakukan dengan termometer air raksa. Berikut merupakan grafik hasil pengukuran suhu dari hari ke-0 sampai hari ke-14 :

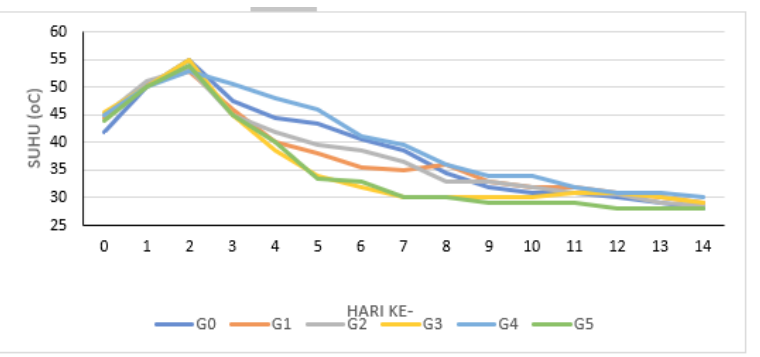

Gambar 2. Grafik Pengukuran Suhu

Nilai suhu meningkat diatas $50^{\circ} \mathrm{C}$ mulai dari hari ke-0 hingga hari ke-3 dan mencapai suhu tertinggi yaitu sebesar $55^{\circ} \mathrm{C}$ pada hari ke-2 untuk reaktor G0 dan G3. Hal ini menunjukkan bahwa pada hari-2 merupakan suhu puncak. Kenaikan suhu ini disebabkan oleh adanya aktivitas bakteri termofilik dalam mendegradasi bahan kompos. Suhu semakin hari semakin menurun dan mendekati suhu tanah. Pada hari ke-7 mempunyai suhu sebesar $30^{\circ} \mathrm{C}$ pada reaktor G3 dan G5 dan telah memenuhi standar kompos matang sesuai dengan SNI 19-7030-2004 yaitu $<30^{\circ} \mathrm{C}$.

Kenaikan suhu juga berpengaruh terhadap pembalikan atau pengadukan pada proses pengomposan. Pembalikan atau pengadukan dilakukan untuk mencampurkan mikroorganisme agar dapat merata ke seluruh bagian kompos. Menurut Schloss (1999), pengadukan sangat berpengaruh pada pencapaian suhu yang maksimum dan memperpanjang periode pengambilan oksigen.

$\mathrm{pH}$

Pengukuran $\mathrm{pH}$ dalam proses pengomposan pada penelitian ini dilakukan setiap 1 kali sehari dengan menggunakan $\mathrm{pH}$-meter. Berikut merupakan hasil pengukuran $\mathrm{pH}$ dalam proses pengomposan pada penelitian ini: 


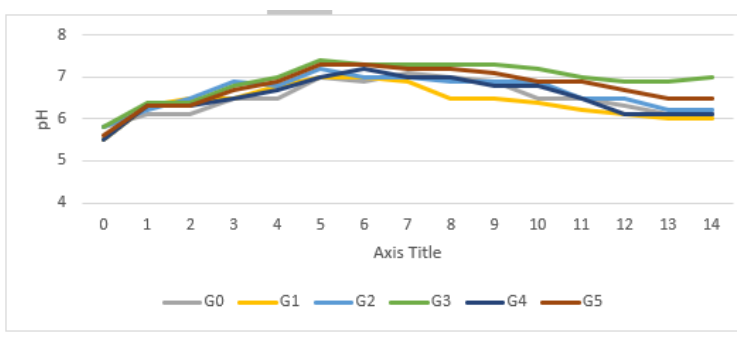

Gambar 3. Grafik Pengukuran pH

Pengomposan awal mempunyai $\mathrm{pH}$ berkisar antara 5-6. Pada awal pengomposan yaitu hari ke- $0, \mathrm{pH}$ bernilai rendah karena adanya aktifitas bakteri mesofil dan pada saat awal pengomposan produksi asam akan meningkat sehingga $\mathrm{pH}$ rendah. Menurut Sidabutar (2012) sejumlah mikroorganisme akan mengubah sampah organik menjadi asamasam organik sehingga derajat keasaman akan selalu menurun. Pada hari ke-7, seluruh reaktor memiliki $\mathrm{pH}$ berkisar antara 6,8-7,2, hal ini telah sesuai dengan syarat kompos matang sesuai dengan SNI 19-7030-2004 yaitu 6,8-7,49. Kenaikan pH juga dapat dikarenakan adanya kenaikan suhu pada proses fase termofilik.

\section{Kandungan C- Organik}

Pengukuran kandungan C-Organik dilakukan dengan metode spektrofotometri. Berikut merupakan hasil pengukuran C-Organik :

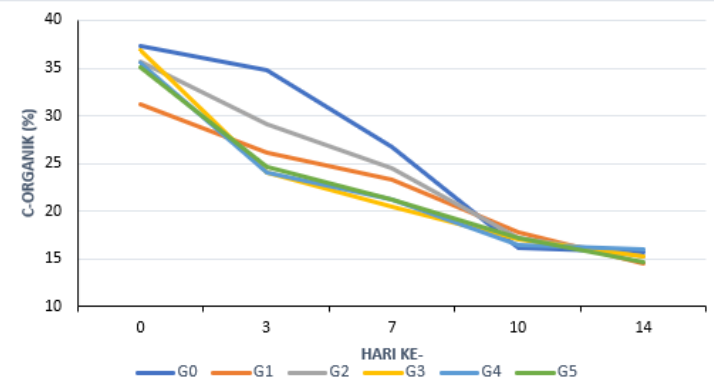

Gambar 4. Grafik Pengukuran C- Organik

Berdasarkan grafik diatas dapat dilihat kandungan C-Organik pada proses pengomposan mengalami penurunan. Persentase penurunan kandungan C-Organik dari yang terbesar hingga terkecil yaitu G3 $(0,588 \%)$, G5 (0,580\%), G2 (0,573\%), G0 $(0,561 \%)$, G4(0,548\%), dan G1 (0,535\%). Menurut Bernal (2009), penurunan kadar COrganik dapat terjadi saat mikroba yang ada di dalam tanah memanfaatkan bahan organik yang ditambahkan ke dalam tanah sebagai sumber energi utama. Setelah bahan organik ditambahkan telah terdekomposisi sempurna, mikroba kembali memanfaatkan bahan organik yang ada di dalam tanah.
Seluruh reaktor telah memenuhi syarat kompos matang sesuai SNI 19-7030-2004 yaitu diantara $9,8-32 \%$. Pada hari ke-0 nilai COrganik yang telah sesuai standar SNI 197030-2004 adalah reaktor G1 karena dibawah $32 \%$. Menurut Kuo et al. (2005), jika terdapat cukup senyawa $\mathrm{C}$ yang mudah didegradasi (gula, karbohidrat, selulosa, dan hemiselulosa) dalam tumpukan yang teraerasi dan terisolasi dengan baik, peningkatan temperatur akan terjadi dalam beberapa hari.

\section{Kandungan N-Total}

Pengukuran N-Total pada kompos dilakukan pada hari ke-0, hari ke-3 dan hari ke- 7 , hari ke-10, dan hari ke- 14. Berikut hasil pengukuran $\mathrm{N}$-Total selama pengomposan:

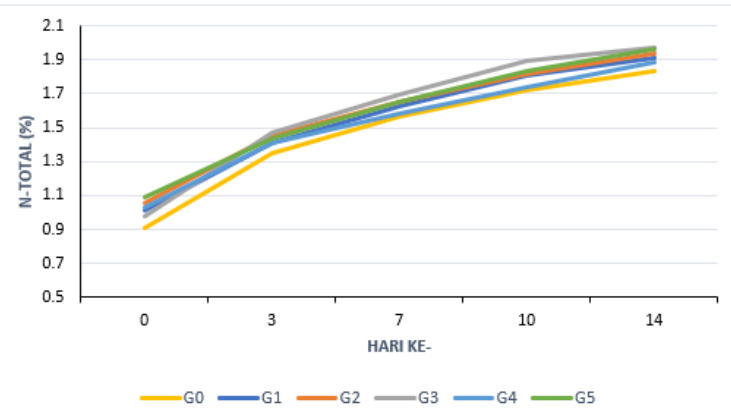

\section{Gambar 5. Grafik Pengukuran N-Total}

Dari data diatas dapat dilihat bahwa kadar NTotal pada seluruh reaktor telah memenuhi persyaratan SNI 19-7030-2004 yaitu minimal $0,4 \%$. Pada hari ke- 0 pengomposan, kandungan $\mathrm{N}$-Total berkisar antara $0,906 \%$ $1,109 \%$. Kandungan N-Total saat pengomposan mengalami kenaikan. Persentase kenaikan N-Total dari yang terbesar sampai terkecil yaitu G0 $(0,507 \%)$, G3 $(0,504 \%), G 1(0,472 \%), G 2(0,457 \%), G 4$ $(0,455 \%)$, dan G5 $(0,442 \%)$. Menurut Fanny (2013), penambahan kadar N-Total disebabkan oleh terlepasnya ikatan nitrogen oksida menjadi nitrogen bebas sehingga menambah kandungan $\mathrm{N}$-Total dalam timbunan kompos yang merupakan hasil dari aktivitas mikroorganisme dalam mendegradasi bahan organik.

Berdasarkan hasil akhir pengujian yang telah dilakukan, semua variasi telah memenuhi standar sesuai dengan SNI 19-7030-2004. Variasi yang memiliki kandungan $\mathrm{N}$-Total terendah adalah $\mathrm{G} 0$ dalam pengujian hari ke$0,3,7,10,14$. Hal ini terjadi dimungkinkan karena sejak awal pengomposan variasi pada reaktor G0 memiliki kandungan $\mathrm{N}$-Total yang paling rendah dibanding reaktor yang lain. Pada pengujian kandungan $\mathrm{N}$-Total pada proses pengomposan, variasi pada reaktor 
G3 yang memiliki kandungan $\mathrm{N}$-Total tertinggi dibanding reaktor yang lain. $\mathrm{Hal}$ ini dikarenakan mikroorganisme lebih aktif mendegradasi bahan pengomposan dan mengakibatkan kandungan $\mathrm{N}$-Total menjadi lebih tinggi.

\section{Rasio C/N}

Berikut merupakan hasil dari pengukuran rasio $\mathrm{C} / \mathrm{N}$ selama proses pengomposan:

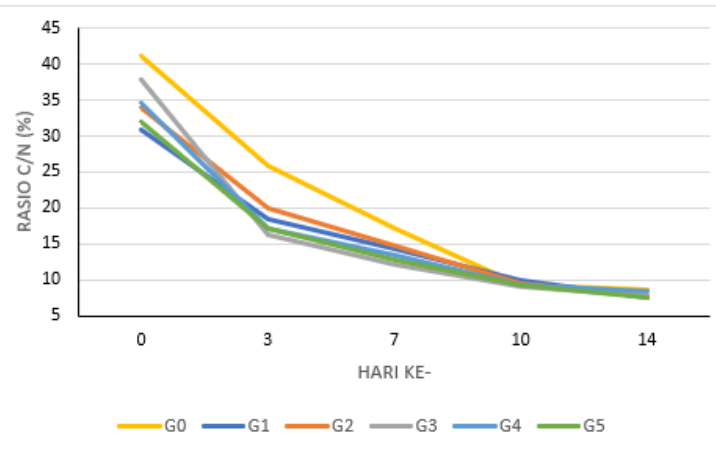

\section{Gambar 6. Grafik Pengukuran Rasio C/N}

Berdasarkan grafik diatas, dapat dilihat bahwa keseluruhan nilai rasio $\mathrm{C} / \mathrm{N}$ pada seluruh reaktor mengalami penurunan. Persentase penurunan rasio $\mathrm{C} / \mathrm{N}$ dari terbesar sampai terkecil yaitu G3 $(0,796 \%)$, G0 $(0,783 \%)$, G2 $(0,768 \%)$, G5 (0,765\%), G1 (0,754\%), dan G4 $(0,753 \%)$. Rasio $\mathrm{C} / \mathrm{N}$ yang paling mendekati 10 yaitu reaktor G3 sebesar 12,09. Hal ini menyatakan bahwa rasio $\mathrm{C} / \mathrm{N}$ pada reaktor G3 dengan penambahan gula pasir 40 gram mengalami waktu pengomposan yang paling optimum. Menurut Yuniwati (2012), penurunan nilai rasio $\mathrm{C} / \mathrm{N}$ disebabkan karena terjadinya penurunan jumlah karbon yang digunakan oleh mikroba sebagai energi untuk menguraikan bahan organik dalam kompos. Selama proses pengomposan terjadi reaksi $\mathrm{C}$ menjadi $\mathrm{CO}_{2}$ dan $\mathrm{CH}_{4}$ yang berupa gas dan menguap sehingga menyebabkan penurunan kadar karbon (C). Sedangkan nilai N-Total dalam bahan organik mengalami peningkatan karena proses dekomposisi bahan kompos oleh mikrooorganisme yang menghasilkan ammonia dan nitrogen, sehingga kadar $\mathrm{N}$ Total kompos meningkat. Dengan menurunnya kandungan C-Organik dan meningkatnya $\mathrm{N}$-Total maka rasio $\mathrm{C} / \mathrm{N}$ mengalami penurunan. Bahan organik sudah menjadi kompos/pupuk dapat digunakan untuk tanaman apabila rasio $\mathrm{C} / \mathrm{N}<20$.

\section{P- Total}

Berikut merupakan hasil uji kandungan $\mathrm{P}$ Total dapat dilihat pada gambar di bawah ini:

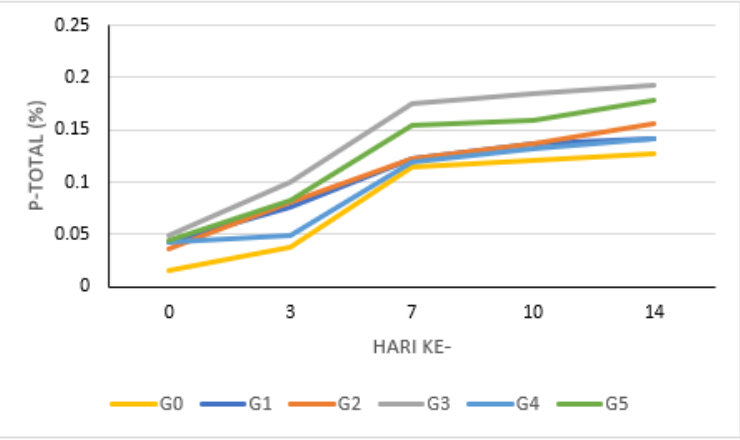

Gambar 7. Grafik Pengukuran P-Total

Berdasarkan data di atas, dapat dilihat bahwa kadar fosfor (P-Total) yang terkandung pada semua reaktor pada awal pengomposan belum sesuai SNI 19-7030-2004 karena masih di bawah $<0,1 \%$. Namun pada hari ke-3 kandungan fosfor pada reaktor G3 sudah memenuhi syarat kompos matang sesuai SNI 19-7030-2004 yaitu sebesar 0,100\%. Reaktor lainnya baru mengalami kenaikan diatas 0,1\% pada hari ke-7. Pada hari ke-7 nilai $P$ tertinggi dimiliki oleh reaktor $\mathrm{G} 3$ dan yang terkecil yaitu G0 sebesar 0,115\%. Hal ini menunjukkan tanpa penambahan gula pasir memiliki kandungan P-Total yang paling kecil, sedangkan dengan penambahan gula pasir sebanyak 40 gram memiliki kandungan PTotal tertinggi. Kandungan unsur $P$ semakin tinggi dengan terjadinya pelapukan bahan organik yang dikomposkan, dalam tahap pematangan mikroorganisme dalam bahan kompos yang secara langsung akan meningkatkan kandungan fosfor dalam kompos (Nurdiansyah, 2015).

\section{K- Total}

Berikut merupakan data hasil pengukuran $\mathrm{K}$ Total:

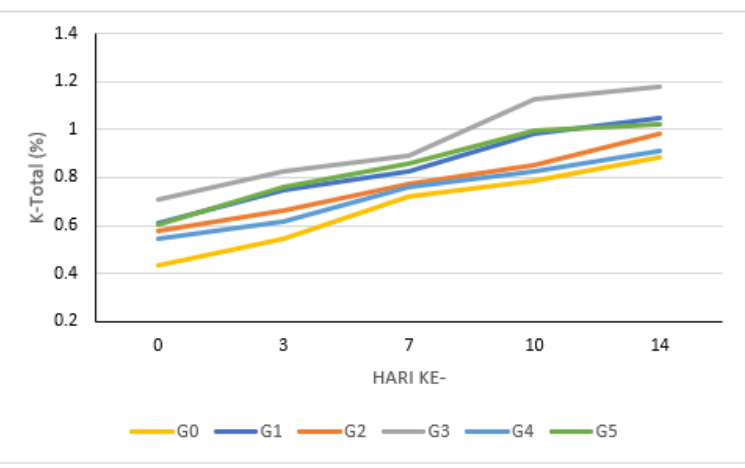

Gambar 8. Grafik Pengukuran K-Total

Berdasarkan data diatas dapat dilihat bahwa kandungan kalium pada kompos mengalami peningkatan. Seluruh reaktor mempunyai kandungan K-Total yang telah memenuhi persyaratan kompos matang sesuai dengan 
SNI 19-7030-2004 yaitu sebesar $>0,2 \%$ dan mengalami kenaikan. Pada hari akhir pengomposan, kandungan K-Total tertinggi dimiliki oleh reaktor G3 yaitu sebesar 1,176\%, dan yang terendah dimiliki oleh reaktor G0 sebesar $0,884 \%$. Hal ini menunjukkan bahwa penambahan gula pasir mempengaruhi nilai K-Total akhir pada kompos. Menurut Walidaini (2016), kalium digunakan oleh mikroorganisme sebagai katalisator sehingga berpengaruh terhadap peningkatan kalium.

\section{Warna dan Bau}

Pada hari ke-0 tumpukan kompos pada setiap reaktor memiliki warna coklat terang dan masih memiliki bau busuk yang menyengat. Bau tiap reaktor masih menghasilkan bau yang dapat tercium sampai jarak \pm 3 meter. Pada hari ke-3 warna kompos pada seluruh reaktor masih sama dan bau sudah mulai berkurang dibanding hari sebelumnya. Namun pada reaktor G3 sudah terlihat perubahan warna coklat kehitaman tetapi masih menghasilkan bau. Pada hari ke7, reaktor G0 sudah berubah warna dari coklat menjadi coklat kehitaman dan bau kompos sudah seperti tanah. Reaktor G1, G2, dan G4 warna kompos masih coklat tetapi bau kompos sudah menyerupai tanah. Reaktor G3 dan G5 warna kompos sudah kehitaman dan bau kompos sudah seperti tanah. Pada hari ke-10, reaktor $\mathrm{G} 1, \mathrm{G} 2$ dan G4 sudah berubah warna menjadi coklat kehitaman dan bau kompos sudah menyerupai tanah. Pada hari ke-14, reaktor G1 dan G2 telah berwarna kehitaman.

\section{Penyusutan Kompos}

Tabel 2. Hasil Pengukuran Berat dan Tinggi Kompos

\begin{tabular}{|c|c|c|c|c|c|c|}
\hline \multirow[t]{2}{*}{$\mathbf{R}$} & \multicolumn{2}{|c|}{$\begin{array}{c}\text { Berat Kompos } \\
\text { (gram) }\end{array}$} & \multirow{2}{*}{$\begin{array}{l}\text { Reduksi } \\
\text { (\%) }\end{array}$} & \multicolumn{2}{|c|}{$\begin{array}{c}\text { Tinggi } \\
\text { Kompos } \\
(\mathrm{cm})\end{array}$} & \multirow{2}{*}{$\begin{array}{l}\text { Reduksi } \\
(\%)\end{array}$} \\
\hline & Awal & Akhir & & $\begin{array}{l}\text { Aw } \\
\text { al }\end{array}$ & $\begin{array}{l}\text { Akh } \\
\text { ir }\end{array}$ & \\
\hline $\begin{array}{l}G \\
0\end{array}$ & 5000 & 480 & 90,4 & 13 & 5 & 61,5 \\
\hline $\begin{array}{l}G \\
1\end{array}$ & 5000 & 389 & 92,22 & 11 & 4 & 63,6 \\
\hline $\begin{array}{l}G \\
2\end{array}$ & 5000 & 394 & 92,12 & 11 & 4 & 63,6 \\
\hline $\begin{array}{l}G \\
3\end{array}$ & 5000 & 444 & 91,12 & 12 & 5 & 58,3 \\
\hline $\begin{array}{l}G \\
4\end{array}$ & 5000 & 555 & 88,9 & 13 & 4 & 69,2 \\
\hline $\begin{array}{l}G \\
5\end{array}$ & 5000 & 519 & 89,62 & 12 & 4 & 66,7 \\
\hline
\end{tabular}

Berdasarkan Tabel 4.15, berat awal proses pengomposan dari seluruh reaktor yaitu 5000 gram atau $5 \mathrm{~kg}$. Sedangkan berat akhir dari proses pengomposan dari yang terkecil sampai terbesar yaitu, G1 (389 gram); G2 (394 gram); G3 (444 gram); G0 (480 gram); G5 (519 gram) dan G4 (555 gram). Hal ini berpengaruh pada reaktor G1, G2 dan G3 dengan penambahan gula pasir masingmasing 20 gram, 30 gram, dan 40 gram menghasilkan kompos yang lebih sedikit dibanding reaktor G0, G4, dan G5.

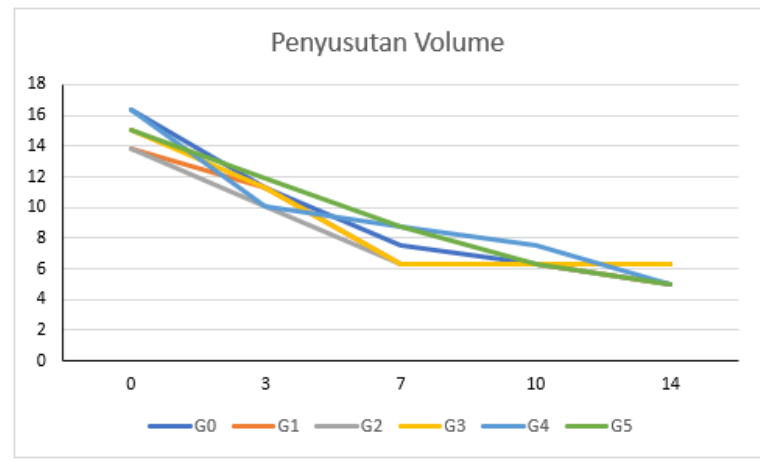

Berdasarkan grafik di atas, penyusutan volume pada seluruh reaktor memiliki penurunan yang cukup signifikan. Presentase penyusutan volume terbesar sampai terkecil yaitu: G4 (69,2\%); G5 (66,7\%); G1 (63,6\%); G2 (63,6\%); G0 (61,5\%); dan G3 $(58,3 \%)$. Penyusutan kompos pada masing-masing reaktor disebabkan oleh pengomposan yang berlangsung terjadinya proses dekomposisi oleh mikrooorganisme yang merubah bahan organik menjadi produk metabolism. Menurut Isroi (2008), bahwa penyusutan volume atau bobot kompos terjadi seiring dengan kematangan kompos. Besarnya penyusutan tergantung pada karakteristik bahan mentah dan tingkat kematangan kompos. Penyusutan kompos pada penelitian ini sudah memenuhi syarat kompos matang menurut Wahyono, dkk. (2011), bahwa penyusutan kompos matang akhir sekitar $50-75 \%$ dari berat awal kompos. Variasi gula pasir pada reaktor G3 (penambahan 40 gram gula pasir) dengan nilai skor 48 pada hari ke-7 telah menunjukkan kompos matang dan yang paling baik diantara variasi lain. Untuk skor terendah terdapat pada reaktor G0 (tanpa penambahan gula pasir) diperoleh nilai 9 pada hari ke-0. Hal ini dapat dikatakan bahwa tanpa penambahan gula pasir mengalami dekomposisi paling lama dibanding penambahan variasi gula pasir yang lain. 
Penentuan Variasi Gula Pasir Optimum Terhadap Waktu dan Kualitas Pengomposan Sampah Sayuran di Pasar Jati Banyumanik dengan Penambahan Bioaktivator Lingkungan (Skoring)

Tabel 3. Waktu Kematangan Kompos dengan Skoring

\begin{tabular}{|c|c|c|c|c|c|c|c|c|c|c|c|}
\hline & Hari ke- & $\begin{array}{l}\text { Kadar } \\
\text { Air }\end{array}$ & Suhu & $\mathrm{pH}$ & Warna & C & $\mathrm{N}$ & $\begin{array}{l}\text { Rasio } \\
\mathrm{C} / \mathrm{N}\end{array}$ & $P$ & $\mathrm{~K}$ & Skor \\
\hline \multirow[t]{5}{*}{ G0 } & 0 & 1 & 1 & 1 & 1 & 1 & 1 & 1 & 1 & 1 & 9 \\
\hline & 3 & 1 & 1 & 1 & 1 & 1 & 5 & 1 & 2 & 2 & 15 \\
\hline & 7 & 2 & 1 & 2 & 2 & 4 & 7 & 4 & 6 & 4 & 32 \\
\hline & 10 & 2 & 1 & 1 & 3 & 8 & 8 & 1 & 6 & 5 & 35 \\
\hline & 14 & 2 & 2 & 1 & 3 & 8 & 9 & 1 & 6 & 7 & 39 \\
\hline \multirow[t]{5}{*}{ G1 } & 0 & 1 & 1 & 1 & 1 & 2 & 1 & 1 & 2 & 3 & 13 \\
\hline & 3 & 1 & 1 & 1 & 1 & 4 & 5 & 3 & 4 & 5 & 25 \\
\hline & 7 & 2 & 1 & 2 & 1 & 5 & 7 & 7 & 6 & 6 & 37 \\
\hline & 10 & 2 & 1 & 1 & 2 & 7 & 9 & 1 & 7 & 8 & 38 \\
\hline & 14 & 2 & 2 & 1 & 3 & 8 & 10 & 1 & 7 & 9 & 43 \\
\hline \multirow[t]{5}{*}{ G2 } & 0 & 1 & 1 & 1 & 1 & 1 & 2 & 1 & 2 & 2 & 12 \\
\hline & 3 & 1 & 1 & 2 & 1 & 3 & 6 & 1 & 4 & 4 & 23 \\
\hline & 7 & 2 & 1 & 2 & 1 & 5 & 7 & 6 & 6 & 5 & 35 \\
\hline & 10 & 2 & 1 & 2 & 2 & 7 & 9 & 1 & 7 & 6 & 37 \\
\hline & 14 & 2 & 2 & 1 & 3 & 8 & 10 & 1 & 8 & 8 & 43 \\
\hline \multirow[t]{5}{*}{ G3 } & 0 & 1 & 1 & 1 & 1 & 1 & 1 & 1 & 2 & 4 & 13 \\
\hline & 3 & 1 & 1 & 2 & 2 & 5 & 6 & 5 & 5 & 6 & 33 \\
\hline & 7 & 2 & 2 & 2 & 3 & 6 & 8 & 9 & 9 & 7 & 48 \\
\hline & 10 & 2 & 2 & 2 & 3 & 8 & 10 & 1 & 9 & 10 & 47 \\
\hline & 14 & 2 & 2 & 2 & 3 & 8 & 10 & 1 & 10 & 10 & 48 \\
\hline \multirow[t]{5}{*}{ G4 } & 0 & 1 & 1 & 1 & 1 & 1 & 2 & 1 & 2 & 2 & 12 \\
\hline & 3 & 1 & 1 & 1 & 1 & 5 & 5 & 4 & 2 & 3 & 23 \\
\hline & 7 & 2 & 1 & 2 & 1 & 6 & 7 & 7 & 6 & 5 & 37 \\
\hline & 10 & 2 & 1 & 2 & 2 & 8 & 8 & 1 & 7 & 6 & 37 \\
\hline & 14 & 2 & 2 & 1 & 2 & 8 & 10 & 1 & 7 & 7 & 40 \\
\hline \multirow[t]{5}{*}{ G5 } & 0 & 1 & 1 & 1 & 1 & 1 & 2 & 1 & 2 & 3 & 13 \\
\hline & 3 & 1 & 1 & 1 & 1 & 4 & 5 & 4 & 4 & 5 & 26 \\
\hline & 7 & 2 & 2 & 2 & 3 & 6 & 7 & 8 & 8 & 6 & 44 \\
\hline & 10 & 2 & 2 & 2 & 3 & 7 & 9 & 1 & 8 & 8 & 42 \\
\hline & 14 & 2 & 2 & 1 & 3 & 8 & 10 & 1 & 9 & 8 & 44 \\
\hline
\end{tabular}

\section{Kesimpulan}

Pada penelitian "Pengaruh Variasi Gula Pasir terhadap Waktu dan Kualitas Pengomposan Sampah Sayurandi Pasar Jati Banyumanik dengan Penambahan Bioaktivator Lingkungan" dapat disimpulkan bahwa:

1. Reaktor G3 yaitu dengan penambahan variasi gula pasir sebanyak 40 gram pada pengomposan sampah sayuran di Pasar Jati Banyumanik dengan penambahan bioaktivator lingkungan dibanding dengan variasi pada reaktor yang lain memiliki waktu kematangan kompos yang paling optimal. Hal ini dapat dibuktikan pada nilai rasio $\mathrm{c} / \mathrm{n}$. Nilai rasio $\mathrm{c} / \mathrm{n}$ pada reaktor G3 yaitu dengan penambahan variasi gula pasir sebanyak 40 gram sudah memenuhi standar SNI 197030-2004 pada hari ke- 3, namun reaktor G3 pada hari ke-7 merupakan waktu pengomposan yang paling 
optimum dengan dibandingkan kembali dengan parameter lainnya.

2. Penambahan variasi gula pasir berpengaruh signifikan terhadap waktu pengomposan ditinjau dari rasio $\mathrm{c} / \mathrm{n}$ pada sampah sayuran dengan ditambah bioaktivator lingkungan. Reaktor G3 berdasarkan metode skoring memiliki waktu pengomposan optimal pada hari ke-7

\section{Referensi}

Mulyani, Happy. 2014. Buku Ajar Kajian Teori dan Aplikasi Optmasi Perancangan Model Pengomposan. Jakarta : Trans Info Media.

Sunarsih, Lilis Endang. 2018. Penanggulangan Limbah. Yogyakarta: Penerbit Deepublish

Kusumawardhani, Farah Huda. 2018. Pengaruh Variasi Komposisi Sampah Pasar Terhadap Waktu Pengomposan dan Kualitas Kematangan Kompos Dengan Bioaktivator Lingkungan. Semarang: Universitas Diponegoro

Schloss, Patrick D., dkk. 1999. The Use of the Analysis of Variance to Assess the Influence of Mixing during Composting. New York: Elsevier.

Amanah, Farisatul. 2012. The Effect of Turning Period and Feedstock to the Septage Mix-Compost Quality. Depok: Universitas Indonesia

Sidabutar, N.V. 2012. Peningkatan Kualitas Kompos UPS Permata Regency dengan Penambahan Kotoran Ayam menggunakan Windrow Composting. Jakarta: Universitas Indonesia. dan memiliki rasio $\mathrm{C} / \mathrm{N}$ sebesar $12,086 \%$ pada hari ke- 7 .

3. Penentuan waktu kematangan kompos dengan parameter rasio $\mathrm{c} / \mathrm{n}$ yaitu pada hari ke-7, dibuktikan dengan seluruh reaktor pada hari ke7 telah memenuhi standar SNI 197030-2004, hanya saja reaktor G3 merupakan variasi yang paling optimum diantara seluruh variasi gula pasir pada reaktor.

Bernal, M.P., Alburquerque, J.A., \& Moral, R. 2009. Composting of Animal Manures and Chemical Criteria for Compost Maturity Assessment. A review BioresourTechnol.

Yuniwati, M., F. Iskarima, A. Padulemba. 2012. Optimasi Kondisi Proses Pembuatan Pupuk Organik Dengan Cara Fermentasi Menggunakan EM-4. Jurnal Teknologi 5(2).

Walidaini, R. 2016. Pengaruh Penambahan Pupuk Urea dalam Pengomposan Sampah Organik secara Aerobik menjadi Kompos Matang dan Stabil. Semarang: Universitas Diponegoro.

Nurdiansyah, A. 2015. Pengaruh Berbagai Tingkat Dosis Effective Microorganism 4 terhadap Rasio $\mathrm{C} / \mathrm{N}$, rasio $\mathrm{C} / \mathrm{P}, \mathrm{pH}$ dan Fosfor Kompos Pelepah Kelapa Sawit (Skripsi). Banjarbaru: Universitas Lambung Makurat.

Isroi. 2008. Kompos. Bogor: Balai Penelitian Bioteknologi Perkebunan

Wahyono, S., F.L. Sahwan, dan F. Suryanto. 2011. Membuat Pupuk Organik Granul dari Aneka Limbah. Jakarta : Agromedia Pustaka. 